\title{
CAN COOPERATIVES BE A RESPONSE TO MARKETING PROBLEM IN AGRICULTURE UNDER RECENT GLOBAL PRODUCTION STRUCTURE? ${ }^{1}$
}

\author{
Özkan LEBLEBİCI \\ Graduate School of Social Sciences, Attlım University \\ E-mail: ozkan.leblebici@atilim.edu.tr
}

doi:10.13165/IE-14-8-1-03

\begin{abstract}
The progress of capitalist mode of production in agriculture has created dependency on industrial production. This kind of dependency to inputs in agriculture causes the terms of trade grow against the producers. However, the liberalisation tendency in agricultural trade, especially in the aftermath of the Uruguay Rounds, increased the integration level of multinational corporations (MNCs). This enables MNCs, leading firms in production chains to render the producers dependent on the production process. Marketing is an important problem for producers in this structure. Producers can hardly access markets without the support of MNCs. Cooperatives may be a solution for such a problem. This study discusses that cooperative organisations could be the structures that enable producers to access the markets despite MNCs.
\end{abstract}

JEL classification: F, F01.

Keywords: cooperative, global value chains, agricultural MNCs, dependency.

Reikšminiai žodžiai: kooperatyvai, globalios vertès grandinès, žemės ūkio transnacionalinès kompanijos, priklausomybè.

\section{Introduction}

Agricultural production has become the most important area in global trade, due to growing population and increasing demand for food. Today multinational corporations (MNCs) are very keen on this profitable business. While we think that "globalization has made MNCs more footloose than ever" (Stopford, 1998), MNCs are trying to control the whole process of the agricultural production. This involves organisation of global value chains to gain the control over the entire process. "Farm to fork" becomes a legitimating discourse in this attempt. Small production companies and peasants as a kind of

1 This paper is a revised and developed version of a study submitted by the author for the 20 International Turkish Cooperatives Congress in 2011. 
producers survive in the context determined by the leading firm of the global value chain. Especially, in the aftermath of the Uruguay Rounds, liberalisation of agricultural trade seems to provide opportunity to MNCs to make profit from agricultural production. Standards set by MNCs make the producers dependent on production processes in order to make market access available.

Market dependency, involving small producers, is like spatial projection of dependency of periphery to centre in the context of centre-periphery dichotomy. Cooperative trading system, formed in the capitalist mode of production in the nineteenth century, is now seen as a hope by producers who have become a part of the global production network in agriculture. This approach can be regarded as coherent as we take the cases into account. In this text, we maintain the idea that cooperatives in agriculture can protect local producers against the global production network led by MNCs. In this context, first, we are going to try to set the global production networks out in agriculture, by using the global value chain approach. Second, we are going to try to explain how cooperatives can support producers in agricultural trade. In order to limit our study, we shall exclude policy issues and focus more on the need of cooperatives for producers in the agricultural production network.

\section{Global Agricultural Production}

Agriculture is a revolutionary step for the humanity, since it had totally changed the social structure and so forth. 8000-9000 BC was the time when the first agricultural production had been realised. This made it possible that one man had produced food for others and the politicians of the time as well (Diamond, 2008: 99-100). That was the beginning of a legendary development story of humanity. Increasing production was the main goal of societies, as they began to live in numbers. But we shall focus on Europe since it has been the motherland of capitalism and agricultural trade.

However, agricultural production in Europe was "spatial exhausting" in precapitalist era (Bloch, 1983: 85), had the scale for production been very small. At the same time, we could say that there was an affiliation between social organisation, land ownership and production. The most important factor for incremental change in agricultural production was the changing nature of land ownership.

Social organisation based on land has played an important role throughout the history. Sparta was an example with its complete social organisation, based on common ownership of land. The Peloponnesian War (431-404 BC) ended with the victory of Sparta against Athens, as their social organisation was based on land (Denis, 1997: 1516). This social organisation based on land with military organisation were applied by the Roman and the Ottoman Empires in various forms. However, the deterioration in the system evolved in favour of private ownership.

Sheltering and security needs in the dark ages of Europe had an important effect on emerging cities with societies living very densely. Agricultural production involving huge space in infertile way had engendered to establishing cities while it had conjoined with prevailing conditions in the middle ages (Bloch, 1983: 85). Güler's (2006: 61) view of the 
emerging cities is the consequence of development in agriculture and is quite similar. As the population of cities has been growing with mostly jobless people, the need for food necessitated agricultural production in a different way and also fostered trade in agricultural product (Köymen, 2008: 37). Especially in England, enclosure movement had abrogated the common ownership of peasants on land and population drawn apart from land had streamed into cities. Toynbee, a famous English historian, explains that the population of five big cities were multiplied by more than a hundred between 1685 and 1881 .

Owners of land (landlords) began to rent the land for cultivation in England, where collective ownership structure had broken down. The rent paid to landlords was adopted under market conditions. Because of this, leaseholders had to find new methods to increase the product. At the triad structure of production, composed of a landlord, a leaseholder and paid agricultural labour, compulsion for maximising profit was concentrated on paid workers with no property. Wood stated that dependence on the market was embodied firstly in agriculture and the existence of agriculture has been a predecessor of industrial capitalism (Wood, 2002: 94-111). At the same time, development in agricultural production had supported industrial capitalism, considering the results as well. Cheap labour needed in industry was made possible by reason of disassociation in the rural area.

Accrual of agricultural products had made the soil inadequate in terms of minerals. Dependence of agriculture on fertilisers had thereby grown. One of the solutions was an artificial fertiliser in the second half of the nineteenth century. Development of dependency on inputs in agriculture also conditioned the development of capitalist mode of production. Law of accumulation and declining profit rate, law of ascending concentration and centralisation of industry, law of growing industrial unemployment, law of ascending poverty of proletariat and law of crises (Ekelund, 1990: 275-278) were developing gradually due to dependency of agricultural production on industry. Cultivation of soil in capitalist way was reducing the price of products, as productivity of agricultural labour was ascending (Erdost, 1988: 62). Capital investment had made cheaper production available while small producers could not make this.

Imperialist era of the capitalism, involving unequal exchange, began in 1900s (Brever, 1990: 187-188). Amin's (1997: 28-29) view on imperialism may be summarised under 5 articles: 1 . Mono world system, organised in centre and periphery, 2 . Hierarchical structure of the multi-relational modes of production, 3. The articulation of periphery to centre and disconnectedness of each other, 4 . International specialization, imposed by centre, 5. Transfer of surplus from periphery to centre. Wallerstein (2005: 51) also stated that the capitalist world economy had divided production as production of centre and production of periphery. This kind of division of labour causes that periphery would choose to produce low added value products, such as agricultural product and mining. Sustainability of this division of labour involves monopoly of centre on some products (Amin, 2000: 42-44), such as: 1. Monopoly on technology, 2. Monopoly controlling global financial movements, 3. Monopoly providing access to natural resources, 4 . Monopoly on mass media and media, 5. Monopoly on weapons of mass destruction. Any attempts of periphery to proceed is dependent on the centre's decision.

Development for periphery imposed by the centre can be seen as a legitimating concept of such hierarchical unequal relations in the context of centre-periphery 
dichotomy (Başkaya, 2005: 18). The so-called "green revolution" of 1960s (Köymen, 2008: 141), the mode of production of which is dependent on industrial products, made the unequal exchange sustainable. At the same time, terms of trade in the long run have deteriorated to the disadvantage of developing countries and this is known as "PrebischSinger Thesis" (Yamak, 2006: 128-143).

In Turkey, there were almost 2000 tractors in 1948 and this number grew up to 40.000 in 10 years. Accrual of urban population was $79 \%$ between 1950 and 1960 due to breakaway of people from rural areas (Köymen, 2008: 138). However, the accrual of productivity in agriculture of industrialised countries ascended overwhelmingly due to the usage of industrial inputs. This changed down the prices of agricultural products against the periphery. However, until 1990s some of the countries could hardly take protective measures with regard to agricultural production.

During the 1970s petroleum crisis developing countries became open to compulsion of developed countries because of their increasing debt (Dikmen, 2000: 285). Uruguay Rounds were held when neo-liberal policies were popular around the world in 1980s. However, agreement on agricultural products could hardly be reached until 1994 when final act was signed. Now we may look at the global importance of production networks and cooperatives.

\section{Cooperatives and their Place in Global Production Organisation}

Cooperatives have undertaken very important functions in solving economic and social problems of the countries since their emergence in the nineteenth century. Their existence in social and economic life has prevailed, although they had developed. Because cooperatives have not only remained a social tool that regulates distribution of income, they also had been a tool for productivity under limited conditions. Furthermore, they had leading effects on societies, it might however have not been clearly obvious. Moreover, they have become an insurance against unfair distribution of income. At this stage, we have to analyse the emerging conditions of cooperatives.

\subsection{Cooperatives in Historical Perspective}

It is important to know the etymology of the word "cooperative". It comes from Latin root word "cooperat". The word "cooperate" defines working or acting together; to be willing to work together (Macmillan, 1983: 222). When we take it as a word; we may conclude that it is a union established by people who are willing to work together. However, cooperatives have gained some meaning in historical perspective.

Studies on emerging of cooperatives may bring them up to establishment of some unions, aiming to co-act in the Roman Empire (Helm, 1979: 1). However, the alleged chronicle on the cooperative movement in the latter sense is different, generally starting from the eighteenth century. It may be alleged that a sample cooperative had first emerged in Scotland in 1761 (Özdemir:14) or that an example of a cooperative organisation had been examined by pioneers like Robert Owen (1771-1851), C. Fourier (1772-1837), L. Blanc (1811-1882), Dr. William King (1786-1865) (Başar, 1983: 44). However, there is a 
common agreement on that consumer cooperative founded by 28 workers in 1844 and known as "Rochdale Pioneers" was the first example of recent cooperatives in the sense of establishment and operating principles.

This leading movement was not smooth. Rochdale pioneers had encountered many problems, varying from distrust to being derided (Mülayim, 1975: 30). However, their endeavours on the way that they believed had made them succeed. This also changed the faith of cooperative movement in the world. At this stage, we should consider the economic and social circumstances in order to help a better understanding of the issue.

As feudalism was weakening and nation states were emerging during the sixteenth and seventeenth centuries, the existence of bourgeois had gradually crystallised. This also made the mercantilist ideal forceful which was promulgated by most nation states in the pre-capitalist era (Rankin, 2011). Uneven development of capitalism, consequent of mercantilist era, had made income distribution ill-balanced in societies. This ill-balanced income distribution had constituted a base for the emergence of cooperatives. Enclosure movement forced people to leave their villages and they began to live in cities as cheap labour force. Thus, great was the destitution that different endeavours took palace to solve the problem of inequality as of the end of eighteenth century (Ürper, 1985: 7).

Robert Owen was the first who reacted in England to the problem of workers employed under heavy conditions in factories. Owen regulated working conditions in his factory in favour of workers. However, competitors launched a campaign against him. Owen failed consequently and went to the USA in 1825. He established cooperative villages entitled "New Harmony" but failed again (Özdemir: 23-24). Although he was an unsuccessful practitioner, his thoughts affected persecutors in any way. Owen is also known as one of the pioneers of utopian socialists (Başar, 1983: 44).

One of the disciples of Owen following his thought in England was Dr.W. King. King, who studied many different disciplines, opened his first consumer cooperative store in 1928 in England. His starting point was to establish an organised union in a capitalist system where workers were to work under unfavourable conditions (Özdemir: 25). Fourier, a French philosopher, known as the commanding figure of the cooperative movement in France, was setting up a social organisation model in order to realise the cooperative life style around the same time. People were to live stand-alone in cooperative villages, which Fourier called "phalansteres", as different from Owen. The daily experience of social groups was planned rigorously in villages (Işıklı, 1983: 32-33).

Germany was another state pioneering cooperative organisations, as England and France in parallel. Consumer cooperative in England, producer cooperative in France and credit cooperative in Germany were the types of developing cooperatives. In Germany, cooperatives were mostly in agriculture in order to overcome the problem of agricultural credit for peasants. The prominent names were Hermann Schulze-Delitzsch and Frederich Wilhelm Raiffeisen (Mülayim, 1975: 34-35). However, they had different approaches to cooperatives in terms of organising and running. Raiffeisen's cooperative approach with its limited organisational structure was consistent with the main principles of cooperatives. Both as an individualist and a liberal, Schulze Delitsche was interested in cooperatives more than others besides being a commercial man and a craftsman as a city folk (Özdemir: 38-39). 
Working class played a historic role in the development of consumer and producer cooperatives in England and France. But in Germany, the development of the cooperative movement was in response to social problems affecting peasants and the middle class (Özdemir: 37-38). In this sense, the purpose of Raiffeisen's cooperatives was to develop peasants economically (Özdemir: 40). Experiments of every country are more or less original in this area. Talking about Turkey, efforts for overcoming some problems in agricultural production established the base for the cooperative movement.

Setting the main principles for cooperatives proceeded in parallel with the development of cooperative organisations. Establishing principles of consumer cooperative found by Rochdale Pioneers constituted the base for the issue. Ten basic principles established by Rochdale Pioneers were anticipated to succeed and result in economic prosperity (Başar, 1983: 45-46). In 1895, the International Co-operative Alliance (ICA) was founded in order to gather all cooperatives under an international umbrella (Başar, 1983: 46). ICA launched a study between 1930 and 1937 and designated the following principles for cooperatives (Mülayim, 1975: 56-57): 1. Absolute principles: free entry, democratic management, distribution of surplus proportionally, giving limited interest for capital; 2. Secondary principles: political and religious neutrality, cash sale, developing training for cooperatives.

In 1966, ICA abolished this classification and set the following six principles (Ürper, 1985: 9-14): open membership, every member's participation in management with one vote, distribution of surplus proportionally, giving limited interest for capital, developing the training for cooperative, making common cause with cooperatives. These principles were reviewed by ICA in 1995 and turned into (Başar, 1998: 661-668): open membership, democratic management, autonomy and independence, economic participation of the member, supporting education, making common cause with cooperatives and responsibility to society.

When a cooperative applies to ICA, its application is considered according to the above principles. These principles also determine the organisational structure of the cooperative. We may regard this economic organisation as an example of a civil society organisation with its democratic management and voluntary entry. If we look at the applications of cooperatives and their structures in different countries, we can understand their role in global production systems.

\subsection{Cooperatives and their Organisational Structures in Different Countries}

Rochdale Pioneer's cooperative approach was economic though Fourier's and Owen's approach was beyond an economic one. Their approach also had social aims. Because of this, they were regarded as pioneers of utopian socialism (Işılkl, 1983: 31-33). Kibbutz and Moshav are a cooperative agricultural organisation in Israel and these kinds of organisations are very close to the thought postulated by Owen and Fourier.

However, seen as a model of cooperative organisations, Kibbutz might be seen as a collective agricultural organisation (Mülayim, 1975: 329). The first Kibbutz was established in 1909 in Israel and was called "Degania". The movement grew to over 270 settlements and 124.000 members, constituted by $2 \%$ of the Israeli population (Ruffle\&Sosis, 2002). Membership of Kibbutz is chosen freely and the structure is egalitarian. Members also play an important role in the army (Ruffle \& Sosis, 2002). 
In Israel, $30 \%$ of agricultural production and $10 \%$ of national income is generated by Kibbutz (Özdemir: 62). Income is distributed equally in Kibbutz regardless of profession, skill or effort level (Ruffle \& Sosis, 2002).

Moshav is another example of an agricultural cooperative settlement in Israel. Moshavs emerged in 1920s and their number grew to over 400. It consists of 60 to 100 families, each of them responsible for their own parcels of land (Sofer, 2001: 365). The main difference from Kibutz is that Moshav is more liberal and non-egalitarian. The main principles of Moshav are as follows (Sofer, 2001: 365-366): state-owned land is allocated to farmer families, self-employed, equal income opportunity, cooperative organisation and mutual assistance. In Moshav, each family is independent and land is leased for 49 years (Mülayim, 1975: 331). Due to industrialisation in agriculture, workforce declined from 15\% in 1960 to 2.9 \% in 1997 in Israel and Moshav's self-employment was gradually replaced by waged employment in 1990s (Sofer, 2001: 366). Both Kibbutz and Moshav were changed due to social and economic developments in the global markets and the importance of their cooperative structure seemed to be declining gradually (Schwarts, 1999).

In Russia, there are state-owned cooperative farms, sovkhozes and kolkhozes, but operating outside the principles of the recent cooperative movement. These collective farming organisations emerged as a consequence of the land regime of the former Russian State, the USSR (Turan, 2011: 309). In 1922, the number of sovkhozes was 4316 with 3324 hectare area and grew up to 5000 in 1928. But in 1937, the number fell down to 342, although the area was that of 8010 hectares (Turan, 2011: 318). After the collectivisation policy implemented between 1928 and 1933, a member of kolkhoz was responsible for cultivating from 0.25 to 0.5 hectares of land and for 1 cow, 2 calfs, 10 sheep, etc. (Nesterova, 2011: 88). Quitting membership in kolkhozes is quite difficult, while entry is simple (Mülayim, 1975: 332-337). In the aftermath of the 1990 Land Reform Act, collective land of sovkhozes and kolkhozes became attractive for privatisation and their structure was changed consequently (Turan, 2011: 318-320).

In the People's Republic of China, agriculture is based on public communes founded in 1958 and consisting of 10 to 12 villages with 20 to 100 thousand people. Communes have had different functions, in addition to incorporating a few cooperatives in them. Production was divided between the commune and the state (Mülayim, 1975: 338-342). Founding of communes caused stagnation in cooperative movement until 1980s. After the 1980s, a "reform" was enacted and this negatively affected the cooperative movement in China. Peasant organisations were dismantled and agricultural production productivity in industrialised regions could be hardly maintained as it had been diminished in other regions (Hinton, 2002: 247). Despite everything, it is alleged that the new organisations and regulations have increased production in general (Dinler, 2000: 178). However, at the same time, a Farmer Specialised Cooperative Law was enacted in 2007 to foster cooperative movement development in agriculture. That Law was adopted in line with the recent principles of cooperatives around the world (Garnevska \& et al., 2011). We may say that neo-liberal transformation has affected the collective farming culture in China.

The EU consists of different countries with different types of cooperatives. Furthermore, regulations for cooperatives in the EU vary from one country to another. However, newcomers to the EU from the former Eastern Block have had some troubles in regulating 
the sector. In the EU, the cooperative thought of a number of countries like France, Italy, Portugal and Belgium is based on the ideological-utopian-cooperative, while some other countries like Denmark and Holland are more liberal (Gutierrez, et al, 2005: 48). Nevertheless, sometimes the EU has legislated regulations on cooperatives. One of those regulations was adopted on 9 July 1987 and concerned contribution of cooperatives to regional development. We can say that the EU considers cooperatives as a tool for regional development. As we think about the main purpose of regional development, which is to diminish the difference of development between regions, it is obvious that the EU places special emphasis on cooperatives. In other words, the EU considers cooperatives not only in economic but also in social terms. Another Council Regulation of the EU on cooperatives was adopted on 22 July 2003 (No 1435/2003) on the Statute for a European Cooperative Society (SCE). This regulation constitutes a legal basis for a SCE (EU, 2003).

When we take into account the market share of cooperatives in the EU, average market share of 8 agricultural products (sheep meat, olives, wine, cereals, pig meat, sugar, dairy, F\&V) is $40 \%$. Four sectors (olives, dairy, wine and to a lesser extent - F\&V) contain branded consumer products (Bijman et al., 2012: 11) and this shows the strength of cooperative structures in the EU. When we consider the nations on the basis of the above-mentioned 8 products, as shown in Figure 1, Finland is the leading country in terms of cooperativisation. In Germany, almost every farmer is a member of one or more cooperatives in agriculture and cooperative managers are professional managers (also in more than $60 \%$ of the EU cooperatives) (Bijman et al., 2012: 31). This means that some cooperatives are quite large in industrialised countries and they may be conceived as corporations in many respects. Merger of cooperatives on the regional level is also another factor that makes cooperatives larger and stronger. Larger cooperatives can apply differentiated cost policies (Bijman, et al., 2012: 43).

Figure 1. Market share of all cooperatives, weighted for 8 sectors (Bijman et al. 2012: 30).

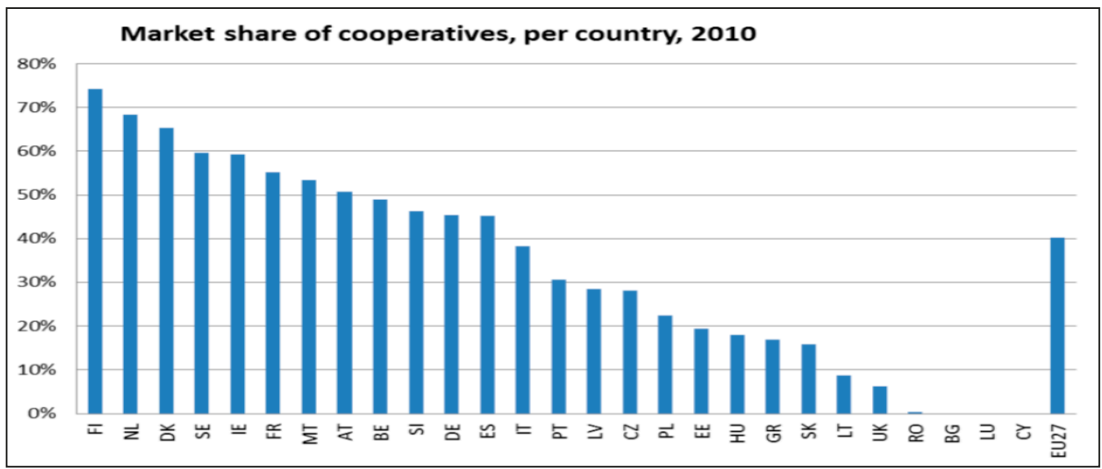

The USA is a remarkable example of cooperative development. In 1995, cooperatives that were founded by farmers sold products for 94 billion dollars and some agricultural cooperatives existed among the first 50 agribussines corporations in the USA (Hudson, 
2000). This brings another issue, namely internationalisation of cooperatives. When a cooperative became internationalised, identity and character of the cooperative had to change in accordance with the principles of cooperatives. For example, open membership principle fails to match international cooperatives (Bijman et al., 2012: 63). Difficulty of democratic management embedded in the spirit of cooperatives is another troubled area for internationalised cooperatives in terms of the changes in the governance structure.

The comparison of 2009 and 2010 cooperative statistics is given below in Table 1. When we look at the table, at first we see that the number of cooperatives fell down to 2310, although memberships showed firm tendency with a little increase. This means that merger of cooperatives is on the agenda. Also in 2010, 2252 of 2310 cooperatives were centralised organisations (USDA, 2010: 2). In addition, 1218 out of 2310 are marketing cooperatives with 734.500 memberships (USDA, 2010: 3). As can be seen, marketing is an important stimulant to make cooperatives be found. Net business volume of the marketing cooperatives is almost \$ 94 billion of \$ 146.1 billion total (USDA, 2010: 7).

Table 1. Comparison of 2009 and 2010 Cooperative Statistics (USDA, 2010)

\begin{tabular}{|l|c|c|c|}
\hline & $\mathbf{2 0 1 0}$ & $\mathbf{2 0 0 9}$ & CHANGE \\
\hline Number of cooperatives & 2310 & 2390 & -80 \\
\hline Memberships (millions) & 2,2 & 2,2 & 0 \\
\hline Gross Business Volume (billion \$) & 170,1 & 169,3 & 0,74 \\
\hline Net Business Volume (billion \$) & 146,1 & 146,9 & $-0,80$ \\
\hline Net Income Before Taxes (billion \$) & 4,3 & 4,1 & 0,16 \\
\hline Total Assets (billion \$) & 65 & 60,8 & 4,2 \\
\hline Full Time Employees (thousand) & 129,3 & 122,2 & 7,10 \\
\hline
\end{tabular}

Although marketing cooperatives have an important place in the USA economy, their number is in downward trend. The number of marketing cooperatives was 1454 in 2006, 1385 in 2007, 1354 in 2008, 1277 in 2009 and 1218 in 2010, while their net business volume is fluctuating in a large margin (USDA, 2010: 27, 30). Some of the cooperatives, integrated vertically and horizontally can survive in such circumstances only by growing in size. And then is this structure called a cooperative? Internationalised cooperative also thereby lose their identity.

In Canada, cooperatives are seen as both social and economic organisations. Furthermore, survival rate of cooperatives is told to be higher than those of other forms of businesses. In a study published in Canada (Richards, 2012: 9), the survival rate of cooperatives changes to $74 \%$ after 3 years of establishment and $44.3 \%$ after 10 years; while the survival rate of other forms of enterprises changes to $48.2 \%$ after 3 years and to $19.5 \%$ after 10 years. The annual revenue of top 50 non-financial cooperatives with 38700 empoyees was $\$ 24.8$ billion in 2010 and $\$ 12.8$ billion in total was the revenue of agricultural cooperatives (Richards, 2012: 12). Nevertheless, cooperatives were confronted with some growth obstacles. One of the problems for cooperatives is accessing financial capital due to lack of knowledge about cooperatives and their structure in the financial sector (Richards, 2012: 26-30). We can say that growth of a cooperative might 
cause its structural change. These kinds of changes might also make the purposes of members different. Then can we say that it is still a cooperative? This question is still awaiting an answer in a capitalist society.

In Turkey, cooperative movement was rooted in 1864, before the Republic. After the establishment of the Republic, great importance was attached to cooperativisation. However, after 1980s, also known as the neo-liberal era, the movement lost acceleration. Five Year Development Plans, regarded as primary policy documents, gave less space to cooperatives during that period. Today there are more than 10000 cooperatives in Turkey. When we look at the market share of cooperatives, we see that it is far below that of the EU and the USA. Producers also take less share of marketing, interceders however take the biggest share (Albayrak et al., 2009). In these circumstances, consumer pays almost 10 times more than the producer takes. Who is the winner then?

\section{Conclusion}

Today MNCs are more powerful than before. Vertical integration of MNCs in agriculture enables them to control the entire production process. Taking into account the fact that the global trade network is a complex system, small producers and farmers are unable to access the market on their own. Integration of MNCs in agriculture also makes farmers and small producers dependent on the process. Developing dependency in such conditions worsens the terms of trade to the disadvantage of small agricultural enterprises. Profit of the MNCs is increasing while the profit of small producers is declining. Both vertically integrated MNCs and retailing MNCs have an important effect on small producers and farmers in marketing. MNCs gain more power gradually and control more share consequently.

In the aftermath of the Uruguay Rounds, global trade in agricultural products has been liberalised. This was a consequence to the disadvantage of developing countries and it also went against farmers and small producers. However, in developed countries, cooperatives were powerful and cooperativisation rates were relatively high, while decooperativisation was on the agenda of developing countries. Producers in developing countries could hardly sustain the production or became a part of the global production network which was directed by MNCs, unless they were members of the cooperatives. If we take the topic of this article into account, the answer is "yes". Cooperatives can be a response to the marketing problem of small producers and farmers.

Cooperatives are both social and economic organisations. By excluding one of those features, an organisation can hardly be called a cooperative. However, from another perspective, cooperatives should make profit from their activities as they are responsible to their members. This is also a contradiction of capitalist societies. We have to know where the border is or how we live in a sustainable environment. Consequently, we should reinvent both the cooperatives and the principles of the historical perspective of cooperatives. 


\section{References}

1. Akbulut, Örsan Ö., (2007), Küreselleşme Ulus Devlet ve Kamu Yönetimi, TODAİE, Ankara.

2. Albayrak, Mevhibe et al., (2009), "Küresel Rekabet Açısından Türkiyede Tarım ve Gıda Ürünleri Pazarlama Sistemlerine Bakış: Mevcut Yapı, Sorunlar, Firsatlar, Hedefler", www. zmo.org.tr, 10.10.2013.

3. Amin, Samir, (1997), Emperyalizm ve Eşitsiz Gelişme, (Çev.Semih Lim), Kaynak Yayınları, (2.Basım), İstanbul,

4. Amin, S. (2000) Değişim Halindeki Dünya Sistemi, (Çev. Fikret Başkaya), Özgür Üniversite, Ankara.

5. Bair, J. (June 2005) "Global Capitalism and Commodity Chains:Looking Back Going Forward”, Competition \& Change, USA, Vol. 9, No. 2, p. 153-180.

6. Başar, H. (1983) Türkiye'de ve Dünyada Kooperatif Kuruluşlarm Sosyo Ekonomik Yapısı, Uludağ Üniversitesi Basımevi, Bursa.

7. Başar, H. (1998) "Kooperatifçilikte Son Gelişmeler ve Türkiye’ye Yansıması", Prof. Dr.Metin Kutal'a Armağan, TÜİS, Ankara, s. 661-668.

8. Başkaya, F. (2005) Kalkınma İktisadının Yükselişi ve Düşüşü, Özgür Üniversite Kitaplığı: 44, 5. Baskı, Ankara.

9. Bijman, J. et al. (2012) Support for Farmers' Cooperatives Final Report, Netherland.

10. Blake, Richards, (2012), Status of Cooperatives in Canada, Report of The Special Committee on Cooperatives, Canada.

11. Bloch, M. (1983) Feodal Toplum, (çev.Mehmet Ali Kılıçbay), Savaş Yayınları, Ankara.

12. Boratav, K. (2009) "Tarımsal Fiyatlar, İstihdam ve Köylülüguün Kaderi”, Mülkiye Dergisi, C. 33, S. 262, Ankara, s. 9-23.

13. Brever, A. (1990) Marxist Theories of Imperialism, Second Edition, Routledge, England.

14. Denis, H. (1997) Ekonomik Doktrinler Tarihi 1, (Çev.Atilla Tokatlı), Sosyal Yayınlar, 3.Basım, İstanbul,

15. Diamond, J. (2008) Tüfek Mikrop ve Çelik, Çev. Ülker İnce, 19. Basım, TÜBİTAK Yayınları, Ankara,

16. Dikmen, A. A. (2000) "Küresel Üretim, Moda Ekonomileri ve Yeni Dünya Hiyerarşisi”, Toplum ve Bilim Dergisi, S. 86, İstanbul, s. 281-302.

17. Dinler, Z. (2000) Tarım Ekonomisi, 5. Basım, Ekin Kitabevi, Bursa.

18. Ekelund, R. B. (1990) Robert F. Herbert, A History of Economic Theory and Method, 3.Edition, McGraw-Hill Publishing Company, Singapore.

19. Erdost, M. İ. (1988) Kapitalizm ve Tarım, Onur Yayınları, (2.Basım), Ankara.

20. Ertuğrul, C. (2004) Tarımda Küreselleşme Uruguay Görüşmeleri ve Sonrası, Odak Yayınevi, Ankara.

21. EC Regulation No 1435/2003 of 22 July 2003 on the Statute for a European Cooperative Society (SCE)

22. Garnevska, E.; Guozhong, L.; Shadbolt, N. M. (2011) "Factors for Successful Development of Farmer cooperatives in Northwest China", International Food and Agribusiness Management Review, Volume 14, Issue 4, IFAMA. 
23. Gereffi, G. “Comodity Chains Framework for Analyzing Global Industries”, Duke University, USA, 1999, http://eco.ieu.edu.tr/wp-content/Gereffi, p. 1-9, 10.06.2011.

24. Gutierrez, A. C. M. et al. (2005) "A Comparative Synthesis of 20th Century Agricultural Cooperative Movements in Europe", Journal of Rural Cooperation, (V.33/1), p. 47-65.

25. Güler, Birgül A. (2006) Yerel Yönetimler, İmge Kitabevi, 3.Basım Ankara.

26. Heffernan, William D. (2002) “Tarım ve Tekelci Sermaye”, Tarım Bolluk İçinde Yoksulluk, (çev.A.Başer Kafaoğlu), Kaynak Yayınları, (2.Basım), İstanbul, s. 129-142.

27. Helm, Franz C. (1979) Kooperatif İşletme Ekonomisi, (çev.İlhan Cemalcılar), Eskişehir İktisadi ve Ticari İlimler Akademisi Yayınları, 2.Baskı, Eskişehir.

28. Hendrickson, M.; Heffernan, W. (Feb. 2002) "Concentratıon of Agrıcultural Markets", University of Missouri, www.foodcircles.missouri.edu/21.06.2011.

29. Hinton, W. (2002) "Çin'in Yeniden İnşasında Toprak Reformunun Önemi”, Tarım Bolluk İçinde Yoksulluk, (çev.A.B.Kafaoğlu), Kaynak Yayınları, (2.Ba.), İstanbul, s. 236-249.

30. Hudson, D.; and Cary, W. (2000) "Bill” Herndon, "Mergers, Acquisitions, Joint Ventures and Strategic Alliances in Agricultural Cooperatives", Department of Agricultural Economics Research Report 2000-09,Mississippi State University.

31. Işıklı, Alpaslan, (1983) Kuramlar Boyunca Özyönetim ve Yugoslavya Deneyi, Alan Yayıncilık, İstanbul.

32. Kaplinsky, R.; Morris, M. (2000) A Handbook For Value Chain Research, IDRC.

33. Köymen, O. (2008) Kapitalizm ve Köylülük, Yordam Kitap, İstanbul.

34. Leblebici, Ö. (2010) "Küresel Değer Zincirleri ve İyi Tarım Uygulamaları", Memleket Siyaset Yönetim Dergisi, C. 5, Say1 14, Ankara, s. 37-63.

35. Macmillan Contemporary Dictionary, ABC Yayınevi, İstanbul, 1983.

36. Mülayim, Z. G. (1975) Genel ve Tarımsal Kooperatifçilik, Bilgi Yayınevi, Ankara.

37. Nesterova, S. (2011) “Kooperatifçilik İlkelere Uygunluğu Bakımından SSCB'deki Kolhozlar ve Kollektivizasyon Politikası", 20.Milletlerarası Türk Kooperatif Kongresi Tebliğleri, Ankara, s. 81-111.

38. Oral, N. (2009) “Türkiye'de Tarım ve Gıda Sektöründe Yabancılaşma ve Tekelleşme”, Mülkiye Dergisi, Ankara, C. 33, S. 262, s. 325-343.

39. Özdemir, N. Kooperatifçilik, Ankara İTİA Yayınları, Ankara.

40. Rankin, K. (2011) "Mercantilist Reasoning in Economic Policy Making", Conference of the New Zealand Association of Economists, Wellington.

41. Ruffle, Bradley J.; Richard H.Sosis (2002) "Just How Cooperative are Kibbutz Members? Field Experiments on Israeli Kibbutzim and in Israeli Cities”, http://sapir. tau.ac.i, 10.11.2013.

42. Schwarts, M. (1999) “The Rise and Decline of the Israeli Moshav Cooperative: A Historical Overview, Journal of Rural Cooperation, (Vol. 27, No. 2), Israel, p. 129-166.

43. Sofer, M. (2001) "Pluriactivity in the Moshav: Family Farming in Israel", Journal of Rural Studies, (17), Israel, p. 363-375.

44. Stopford, J. (1998) "Multinational Corporations", Foreign Policy, USA.

45. TCA (2009) Decision by Competition Board in 06.08.2009 with no. 09-35/891-214. 
46. Toynbee, A. "Lectures on The Industrial Revolution in England,1884", http://socserv.mcmaster. ca/ econ/ugcm/31l3/toynbee/indrev, 11.07.2011.

47. Turan, M. (2011) "SSCB'de Toprak Mülkiyeti”, Mülkiye Dergisi, (C. 66, No: 3), Ankara, 307-332.

48. USDA, Cooperative Statistics, United States Department of Agriculture, 2010.

49. Ürper, Y. (1985) Türkiye'de Tarımsal Kooperatiflerin Toplumsal Değişmeye Etkileri, Anadolu Üniversitesi Yayınları, Eskişehir.

50. Wallerstein, I. (2002) Tarihsel Kapitalizm (çev.Necmiye Alpay), Metis Yayınları, 3.Basım, İstanbul.

51. Wallerstein, I. (2005) Dünya Sistemleri Analizi Bir Giriş (Çev.Ender Abadoğlu, Nuri Ersoy), Aram Yayıncılık, 2.Basım, İstanbul.

52. Wood, E. M. (2002) "Kapitalizmin Tarımsal Kökenleri”, Tarım Bolluk İçinde Yoksulluk, (çev.A.B.Kafaoğlu), 2.Basım, Kaynak Yayınları.

53. Yamak, R.; Korkmaz, A. (2006) "Prebisch-Singer Hipotezi ve Küçük Açık Ekonomi Varsayımı”, Selçuk Üniversitesi Karaman İ.İ.B.F. Dergisi, Sayı 10, s. 128-143.

\section{AR GALI KOOPERATYVAI IŠSPRĘSTI MARKETINGO PROBLEMĄ ŽEMĖS ŪKIO SEKTORIUJE DABARTINĖMIS GLOBALIOS PRODUKCIJOS STRUKTŪROS SĄLYGOMIS}

Santrauka. Kapitalistinio gamybos būdo raida žemès ūkyje sukūrẻ priklausomybę pramonès produkcijai. Ši priklausomybè nuo pramonès žemès ūkyje sukelia situaciją, kad tarptautinè prekyba turètų augti. Tačiau prekybos žemès ūkio produktais liberalizavimo tendencijos, ypač po Urugvajaus raundų, padidino transnacionalinių korporacijų (TNK) integracijos lygị. Tai daro TNK pirmaujančiomis gamybos grandinėse ir telkiančiomis gamintojus ị gamybos procesą. Rinkodara yra svarbi problema gamintojams šioje struktūroje. Gamintojai vargu ar gali patekti i rinkas be tarptautinių korporacijų paramos. Kooperatyvai gali būti tokios problemos sprendimas. Šiame tyrime tai aptarta, kad kooperatyvai galètų sudaryti struktūras, kurios leistų gamintojui patekti ị rinkas, nepaisant TNK.

Özkan LEBLEBİCI - Phd. in Administrative Sciences and Vice-Manager of the Graduate School of Social Sciences in Atılım University.

Özkan LEBLEBİCİ - Socialinių mokslų daktaras, Socialinių mokslų Atilim universitetas. 